\title{
ENSINO SECUNDÁRIO: A HEGEMONIA DO ENSINO ACADÉMICO
}

\author{
Liliana Rodrigues \\ Universidade da Madeira \\ Departamento de Ciências da Educação \\ liliana@uma.pt \\ http://www.uma.pt/liliana
}

\section{RESUMO:}

O ensino secundário tem por objectivos fundamentais o desenvolvimento do raciocínio, da reflexão e da curiosidade científica. Assenta ainda na facultação de contactos e experiências com o mundo do trabalho e, como tal, procura favorecer a orientação e formação profissional dos jovens, através da preparação técnica e tecnológica, com vista à entrada no mundo do trabalho. Nesse sentido esse trabalho busca apresentar historicamente o desenvolvimento do ensino secundário e sua hegemonia com o ensino acadêmico em Portugal e na Europa. Apresenta também que a diferenciação uniformizadora do ensino secundário não passa de uma integração situada entre o cientismo e a publicidade. Será mais importante repensar modos de introdução do pensamento crítico no mundo do que instruir para a função especializada no mercado de trabalho. É o momento em que a educação capitalista se assume como adestramento. Quem melhor assegura os resultados neste tirocínio é a ideologia. Por ela são construídos significados por conveniência política, social e económica.

Palavras-chave: Ensino Secundário - Ensino Técnico - educação capitalista

\section{SECONDARY EDUCATION: THE HEGEMONY OF ACADEMIC TEACHING}

\begin{abstract}
:
Secondary education aims at developing fundamental reasoning, reflection and scientific curiosity. Is also based on any supply of contacts and experiences with the world of work and, as such, seeks to encourage the guidance and training of young people by preparing technical and technological, with a view to entering the world of work. In that sense this study presents the historical development of secondary education and its hegemony in academic teaching in Portugal and Europe. Also shows that the differentiation standardizing secondary education is just an integration of between scientism and advertising. It will be more important to rethink ways of introducing critical thinking in the world than to instruct the specialized function in the labor market. It is the time when the capitalist is assumed to education training. Who provides the best results in this apprenticeship is ideology. Meanings are constructed by it for political expediency, social and economic.
\end{abstract}

Keywords: Secondary Education - Technical Education - education capitalist

O ensino secundário tem por objectivos fundamentais o desenvolvimento do raciocínio, da reflexão e da curiosidade científica. Assenta ainda na facultação de contactos e experiências com o mundo do trabalho e, como tal, procura favorecer a orientação e formação profissional dos jovens, através da preparação técnica e tecnológica, com vista à entrada no mundo do trabalho.

$\mathrm{O}$ ensino secundário, no passado, não estava destinado às massas. Com uma orientação académica, tinha por fim a universidade, acessível apenas a alguns. A unificação deste ensino ocorre no século XX sob a égide da igualdade de oportunidades. 
Os seus efeitos foram contrários, se não perversos: à unificação do ensino secundário correspondeu a estratificação e selecção que distingue os bons dos maus alunos.

Os ensinos técnico e profissional ficaram sob a alçada da escola, nos séculos XVIII e XIX, perante a nova ordem industrial. É curioso observar que o saber fazer era visto como uma douta sabedoria que acabou por se transfigurar pela única oferta escolar possível para os filhos dos trabalhadores. Em termos europeus, a expansão do ensino secundário dá-se após a II Guerra Mundial.

A nível mundial a expansão do ensino secundário, com diversas ofertas curriculares, dá-se nos anos 40 do século XX. Diversos tipos de escolas garantiam que o ensino académico não era massificado. $\mathrm{O}$ ensino secundário sempre se assumiu com uma matriz liceal onde a hegemonia do currículo académico exclui tudo o que lhe seja diferente, nomeadamente as vias técnicas e profissionais. Esta hegemonia não se furta aos interesses sociais, às relações culturais e ideológicas, situada entre um ensino básico e um ensino superior que, sendo propedêutico, encara o ensino secundário como um prolongamento do ensino obrigatório. Em Portugal a ditadura salazarista decreta o estatuto do ensino técnico em $1948^{1}$.

Em Portugal a frequência destes cursos, na área do comércio e da indústria, servia a pouco mais de um quarto da população social economicamente fragilizada e que recebia não só uma formação geral como se procurava desenvolver aptidões profissionais. Também fazia parte desta educação a inculcação dos valores morais e sociais absolutos como o poder político então vigente. Ainda que o Estado Novo reconhecesse o direito dos filhos dos trabalhadores à educação, nem por isso este subsistema deixou de ser secundarizado. A sua secundarização era sempre em relação ao ensino liceal.

$\mathrm{O}$ enciclopedismo e racionalismo das vias de matriz liceal estando desligadas do mundo concreto parecem, pois, talhados a um ensino académico que visa uma cultura de elites que vê nas outras vias de formação segundas oportunidades escolares. É a depreciação e a assunção da fraca nobreza das outras vias do ensino secundário.

A distinção de alunos capazes e alunos incapazes tem sido produzida através da frequência das diferentes vias de ensino dentro do sector escolar: ensino geral/académico, ensino técnico e ensino profissional ${ }^{2}$. O modelo escolar tanto pode oferecer as diversas vias de ensino em escolas próprias (modelo bipartido) como acolher os diversos cursos no mesmo espaço fomentando a diversidade curricular e cultural (modelo compreensivo). Aqui, no último caso, temos não só uma escola comum como um currículo comum de onde todos os outros currículos são variações. Isto é, tanto o ensino tecnológico como o ensino profissional são subsistemas do ensino secundário.

Com os subsistemas de ensino nasceram as disciplinas académicas, técnicas e/ou práticas. Ou seja, temos, por consequência, a categorização dos alunos em académicos e não académicos. Temos a cabeça, mais do que as mãos ${ }^{3^{3}}$. É o momento em que o status revela um padrão social: à divisão social do conhecimento vai corresponder a divisão social de trabalho. Mas nem por isso a escola deixa de educar. Ela é a garantia de transfer para o ensino superior dos alunos das classes mais beneficiadas económica e culturalmente.

Dentro do ensino secundário é possível encontrar uma hierarquia de prestígio que abrange considerações sociais, salários, tipos de escolas, de professores e formadores. Mais, é nele, no ensino secundário, que encontramos selecção social, particularmente através do ensino académico. As consequências da tirania académica escolar têm sido desastrosas: insucesso e abandono escolar e representações negativas sobre tudo o que não sejam cientismos. Todas as outras aprendizagens possíveis são tidas como segundas oportunidades, ou segunda escolha para os que não foram capazes. Elas não são vistas 
como modos diferentes de desenvolver aprendizagens. Em última análise: de produzir conhecimentos.

O ensino técnico e profissional tem a sua legitimação, não no paradigma da continuidade mas numa identidade que se guia pelo paradigma de contexto de trabalho, numa lógica económica que se propõe a contribuir para o desenvolvimento nacional. Estas vias de ensino assumem assim a ampliação de competências técnicas e profissionais dentro de uma estrutura tecnológica, comercial e industrial. Sendo um ensino técnico vocacionado para especializações tem, nos seus currículos, componentes fortemente teóricas e científicas. Daí que o ensino técnico-profissional tenha uma estreita relação curricular com as disposições mais gerais e tradicionais do ensino académico. No entanto, a sua finalidade não é o ensino superior mas a integração imediata no mundo do trabalho.

$\mathrm{Na}$ União Europeia cerca de $54 \%$ dos alunos frequentam o ensino técnico e profissional que é tido como uma aprendizagem ao longo da vida onde as capacidades e os interesses dos alunos devem ser revelados pelo princípio da igualdade de oportunidades. No entanto a par com o conceito de igualdade de oportunidades aparece a ideia de mérito. E esse mérito revela-se a modo de responsabilidade individual e social, com consequências também elas individuais e sociais.

Acreditamos que uma escola que selecciona exclui. O ideal democrático é realizável numa escola onde coexistem diferentes culturas. E o ensino secundário será tanto mais democrático quando os saberes teóricos e os práticos, os abstractos e os concretos, os humanísticos, científicos e artísticos e técnicos ${ }^{4}$ alcançarem a humildade científica e uma dimensão social em que nenhum saber é excepcional. E isto tanto serve à escola pública como ao ensino privado. De uma maneira ou de outra, a educação não é uma empresa onde concorrem privados e públicos a fim de ser ver quem tira maiores proveitos. O ensino técnico-profissional deve constar das ofertas curriculares do ensino público.

A falta de qualidade e as dificuldades de implementação nas escolas públicas são os principais obstáculos à abertura dos cursos técnico-profissionais nas escolas públicas portuguesas. Ainda que esta possibilidade esteja legalmente decretada em Portugal (Portaria 550-C/2004) não existe um corpo docente capaz de garantir qualidade precisamente por não terem formação adequada nesta área de ensino. Isto leva-nos a outra questão que é a de formação de professores na área do ensino técnico-profissional. A sua inexistência, na formação inicial, em Portugal tem feito com que os professores do ensino académico assumam a leccionação das componentes sociocultural e científica no ensino técnico-profissional. A maior dificuldade incide no desconhecimento sobre as metodologias de avaliação e de estratégias de aprendizagem nesta via de ensino onde se apela à visão de que o aluno é o centro do processo pedagógico.

A própria universidade é acusada de não ter competência científica para dar este tipo de formação e de informação. As universidades portuguesas parecem não estar preparadas para levar a cabo orientações de estágio justamente porque os orientadores não detêm competências sobre a prática do ensino profissional. A desadequação da universidade à realidade implica a sua condenação ao fracasso porque se demitiu do ensino secundário, da realidade, do trabalho e porque não tem uma causa comum. As visões teóricas universitárias, em geral, de pouco ou nada servem para quem está no terreno. Talvez a universidade portuguesa deva repensar a formação que é dada na formação inicial.

Só assim é que a formação pedagógica dos professores da componente técnica deve ser deixada a cargo das universidades ou de centros especialmente criados para os formadores do ensino profissional. Sugerimos que a própria universidade providencie 
formação contínua aos professores e formadores do ensino profissional através de parcerias com as entidades oficiais responsáveis pela área da Educação. Cremos que são os investigadores que estão em melhor posição de dar este tipo de formação.

É urgente dar formação aos professores que irão abraçar o projecto do ensino técnico-profissional e não descurar do plano anual de actividades. A educação informal não pode ser negligenciada e os próprios estágios profissionais têm que se mostrar interessantes e com relação com o próprio curso. Se assim não for, o ensino profissional segue os mesmos erros do ensino académico.

São os projectos que melhor caracterizam o ensino profissional, particularmente a nível de avaliação. São eles que trazem inovação e comunicação com o mundo empresarial. Infelizmente a escola continua a promover, de facto, um currículo desinteressante quando publicita o oposto. O que temos dentro da escola, mesmo aquela que assenta no modelo compreensivo, é uma microsociedade meritocrática. A escola sendo acessível a todos não garante o êxito de todos. Prisioneira da sua própria formação e das contingências sociais e económicas, a escola cumpre duas funções: a função de parquear os jovens num cenário de desemprego, já que não é capaz de oferecer uma especialização no ensino pós-secundário, e a função de regular socialmente, seleccionando, as aspirações de mobilidade social dos jovens.

Em alguns países europeus os alunos são colocados com alguma facilidade no mercado de trabalho. A ideia de que apenas os melhores, os que se esforçaram e investiram na escola podem ser seleccionados para a vida activa é assim desmistificada pelo caso austríaco onde a taxa de colocação no mercado de trabalho ronda os $95 \%$.

$\mathrm{Na}$ Europa foi feito o ajustamento entre o desemprego juvenil, a formação e as necessidades do mercado. A descentralização e a flexibilização do ensino profissional na Europa, nos anos 90 do século XX, implicaram a sua privatização deste percurso educativo já que a aposta maior era o ensino geral, portanto, académico. No entanto, criou-se uma maior paridade entre os cursos técnico-profissionais e cursos académicos através da qualificação nível III e da possibilidade de prossecução de estudos.

No espaço europeu criou-se a ideia de que o prosseguimento de estudos seria a garantia de uma melhor colocação no mercado de trabalho. A par com esta ideia cresciam os Estados democráticos que prometiam a superação da desigualdade social numa lógica de produtividade afiançada pela mão-de-obra qualificada e especializada que os sistemas escolares fornecessem. Mas foi a orientação educacional nos anos 50 do século XX que fez da educação a dilação da estadia dos jovens no sistema escolar.

Sem emprego para lhes dar, num ardil educacional que obedece essencialmente às dimensões sociais e económicas, os diversos Estados retardam a entrada no mercado de trabalho e garantem a diminuição, ou pelo menos a estabilidade, do desemprego juvenil. É a massificação do ensino secundário que, por sua vez, faz nascer acesos debates entre as vias alternativas ao ensino académico.

O ensino técnico e profissional estão intimamente ligados a uma educação formal que serve aos interesses económicos do Estado e que por ele é regulamentado em termos de mão-de-obra especializada necessária. É o momento em que a economia põe a política ao seu serviço, nascendo assim um vínculo entre qualificação profissional e desempenho positivo da economia. Foi o que aconteceu com a Reforma Veiga Simão, nos anos 70, que ao procurar modernizar Portugal canalizou os alunos para o ensino técnico-profissional não pelas suas vocações mas para garantir o elitismo do ensino académico.

Com a Revolução de Abril em 1974 deu-se a erradicação, quase total, deste tipo de ensino das escolas portuguesas. Entendia-se que o combate às desigualdades sociais passava pela oferta de um único modelo: o ensino liceal. A aversão à reprodução social 
intimamente ligada ao ensino técnico e profissional, por sua vez conectado com as classes mais desfavorecidas, levava ao currículo one fits all. É o tique ideológico que nos recorda modelos curriculares fabris únicos e que nos comprova que os extremos se tocam. Por outro lado, este fenómeno de igualdade social através do ensino liceal levou ao congestionamento das universidades e só nos anos 80 é que Portugal reabilita o ensino técnico e profissional em nome da competitividade. Com os olhos postos na Europa nasce o vocacionalismo com a Reforma Seabra. O ensino técnico-profissional é introduzido de forma imediata nas escolas secundárias portuguesas.

Perante uma Europa competitiva, diversos parceiros sociais e económicos são mobilizados, mas em Portugal foram são deixados os professores que viam na introdução do ensino técnico-profissional nas escolas públicas algo que desprestigiava o seu estatuto social. Isto significa que as representações sociais e culturais acerca deste tipo de ensino ainda subsistiam depois de quase uma década de democracia. Inclusive as próprias entidades patronais não reconheciam estas qualificações escolares. A fraca divulgação deste tipo de ensino e a assunção de que é um ensino de segunda oportunidade ${ }^{5}$ fez nascer uma representação que se este ensino é de segunda, menos nobre, para os que não foram capazes, também os alunos são de segunda categoria.

De facto, não temos e não podemos todos de ir para a universidade. No entanto, no fim dos anos 80 do século XX foi bastante valorizada a formação geral e sugerido que o ensino profissional e vocacional tivesse uma maior formação teórica e que o ensino académico tivesse componentes vocacionais. De uma maneira ou de outra, com ou sem atender à vocação dos alunos, a demissão social da escola secundária é visível quando tanto defende os valores da democracia e da liberdade como os valores capitalistas e economicistas. Foi a sobrecertificação académica, tanto a nível do ensino secundário como do ensino superior, que fez nascer a diferenciação escolar no ensino secundário. Mas não existem provas que demonstrem a relação entre ensino técnico e profissional e criação de emprego. Mesmo com a aproximação entre os cursos gerais e os cursos profissionais o desemprego mantém-se. Paradoxalmente o ensino secundário continua a ser procurado num mundo, tanto escolar como laboral, que se avizinha altamente competitivo.

A emulação já não se dá à saída da escola, mas dentro da própria escola. Por isso mesmo, a diversificação dos currículos do ensino secundário não incide sobre possíveis inquietações sociais, mas antes sobre o problema do desemprego. Aqui, o ensino liceal é bastante abalado já que o ensino académico não garante qualquer tipo de colocação no mercado de trabalho porque ele é uma qualificação desqualificada. A base escolar em que assentam outras vias de ensino, nomeadamente o ensino técnico-profissional, nada mais são do que versões do ensino geral ligeiramente modificado, particularmente através da componente sociocultural e científica.

Decidiu-se assim, na escola, quem trabalha com a cabeça e quem trabalha com as mãos. A credibilidade dos diplomas das vias técnicas e profissionais continua a ser diminuída ainda que a função propedêutica do ensino secundário se sobreponha à função terminal. Na Europa insiste-se e assiste-se ao retorno da pedagogia dos três R's e no desenvolvimento do espírito empresarial ${ }^{6}$ o que nos ensombra culturalmente.

A escola cultural foi e tem sido secundarizada perante uma Europa global que no passado defendia o Homem Novo. Homem este que não só contribuía para o progresso como para o engrandecimento intelectual e até mesmo, não tenhamos medo da palavra, metafísico de uma época e de um povo. Já não lemos Goethe. Lemos empreendedorismo. Já não discutimos aspectos filosóficos da existência humana. Discutimos o preço que é viver. A educação segue o mesmo caminho. 
Não recusamos a instrução. É urgente repensarmos meios para promover a literacia e temos consciência que a assimilação de informação passa pelas aptidões básicas de ler, escrever e contar. Sendo necessárias, mas não suficientes, estas competências serão o motor de desenvolvimento de proficiências pessoais e profissionais. Educar é reconhecer que a instrução é apenas um meio, não um fim em si mesmo. Educar e ser educado é uma opção que torna possível a reflexão e a crítica.

A corrida ao ensino técnico e profissional tem por móbil fundamental a Europa industrial e comercial que desvaloriza o ensino básico por ser elementar e que pretende a desmobilização para o ensino superior, particularmente nas áreas das ciências menos duras. Teremos pois que admitir que há uma franca aposta do ensino profissional a nível europeu.

O ensino público português tem um quadro de professores e é a eles que recorre sempre que precisa. Não havendo professores formados na área técnica, o Estado opta por não oferecer esta via de ensino aos alunos. Poderia o Estado português seguir o exemplo austríaco, adequando-o, e dar formação aos quase 60 mil licenciados desempregados ${ }^{7}$ e garantir uma equipa técnica de qualidade nesta via de ensino secundário.

Desde 1993 que, por toda a Europa, se deu um desinvestimento formal neste tipo de ensino, inclusive por parte do Fundo Social Europeu. É óbvio que esta oferta curricular contribui, de algum modo, para a subtracção das taxas de abandono e de insucesso escolar precisamente porque são dadas alternativas curriculares ao currículo académico.

A par com uma supervisão adjacente por parte do Estado há que encontrar no ensino secundário profissional o desafio que exige uma reflexão inadiável sobre as dimensões do currículo. O currículo é uma questão valorativa: de quem são os valores? Para quem e para que servem? A quem servem? Quais as forças que estão por detrás do processo valorativo? São sinal de quê? É uma questão epistemológica, pois trata do conhecimento e da verdade: o que deve ser ensinado? O que é que constitui conhecimento válido, ou verdadeiro? A escola não pode ser o lugar da reprodução social implicitamente irreconhecível nas práticas pedagógicas e institucionais. Ela não pode naturalizar o que não tem natureza: o ser humano.

Uma teoria do currículo deve questionar as concepções de sujeito e subjectividade: o que é e quem é esse alguém a quem se pretende operar uma mudança? Em quem (ou no quê) se pretende transformar esse sujeito? O currículo é também o lugar das relações de poder: o que motiva o processo? Que relações mantém a escola com as outras instituições? Porquê essa transformação e não outra? Um currículo é um sintoma de quê? Há indicadores que nos mostram que o currículo é o lugar onde se processam pessoas certificando-as com um lugar na hierarquia social.

É aqui que a escola deve reflectir e assumir a sua finalidade ética e moral: formar o pensamento crítico e não cooperar numa neutralidade agonizante para a reprodução social. Todas as actividades intelectuais (que são actividades evidentes no ensino secundário geral e profissional), na sua essência, são críticas e por isso mesmo, a educação tem o dever de libertar os homens da ignorância, da miséria e do despotismo.

Se a educação pretende ser o esclarecimento do todo pelas partes e se o ensino técnico-profissional é revisto no que de mais raso tem o conhecimento, então a cientificidade ou não do currículo, por comparação aos cursos académicos, depende mais das escolas e dos professores do que dos alunos. Neste sentido e em última análise, a não cientificidade reside nas escolas (que aprovam os programas) e nos professores e não nos currículos do ponto de vista programático já que são os professores e formadores que 
constroem o currículo (em termos de programas) sob a orientação distante do Ministério da Educação.

A resistência dos professores ao carácter científico do ensino técnico e profissional deve-se à certeza inexplícita de que o nosso conhecimento não admite limitações. No entanto, apelamos muitas vezes ao testemunho alheio, inclusive ao senso comum, para garantirmos essa mesma certeza. A simplificação das nossas crenças em sistemas experienciais, seja por hábito ou pela associação, permitem a enunciação mesmo que ilegítima dessas crenças.

Mas é possível a sua rejeição através de uma nova crença. É a pretensão de verdade que não raras vezes se confunde com crença. Por isso mesmo é que tendemos a encontrar no ideal académico a verdade. Mas seja no ensino académico, seja no ensino pragmático a verdade é que os objectos nos são desconhecidos devido à sua própria natureza. Ora, todo e qualquer conhecimento advém da experiência e é esse o carácter perfectivo da educação: assumir que a educação é sempre uma tarefa a realizar. Contrariamos a crença de que o ensino académico é um saber realizado. A educação, seja ela qual for, é de facto um projecto, uma aprendizagem ao longo da vida.

Se a organização e a construção do conhecimento e do mundo assenta em crenças, não menos verdade será admissão da ideologia como motor de endoutrinação e manutenção da cultura produzida e produtora da consciência colectiva. Se recuarmos ao Estado Novo em Portugal há uma conotação do ensino técnico e profissional às classes desfavorecidas que se mantém nas representações sociais contemporâneas. É o momento em que o conhecimento se enclausura no conhecimento. A negação do ensino técnicoprofissional nos currículos portugueses após a Revolução de Abril é sintoma disso.

É o momento em que o imprinting cultural concretiza a verdade ou a falsidade e, neste sentido, transita entre os espíritos individuais. É a falta de abertura, dirigida por crenças oficiais e por ideologias, que afiança o conformismo intelectual e a normalização. É, admitamos, a submissão social verificável pelos alunos que admitem um destino quase fatal que é o mundo comum. É também o momento em que alguns professores recusam tudo o que não cabe nas suas próprias convicções. Assim nascem um conjunto de paradigmas e estereótipos que evitam o diálogo enquanto permuta cultural. A inexistência desse diálogo na formação inicial e contínua agudiza e fortalece ainda mais estas doutrinas escolares. O avanço cultural e escolar é possível, em geral, por condições instáveis. Mas é também pela conjuntura que a autonomia no processo educativo faz emergir novas ideias.

Se a educação é uma escolha individual, as ofertas educativas e curriculares terão que ser forçosamente institucionais. É a renovação perante pressões sociais dada sempre em contexto cultural. Essa regeneração caracteriza-se como resistência ao imprinting. As dificuldades de implementação do ensino técnico-profissional muitas vezes resume-se à manutenção do mesmo. Aí a escola transforma-se no lugar da mesmidade. A transgressão da identidade escolar aparecia aqui sob a forma de ensino técnico-profissional.

O marco histórico deste tipo de ensino indica-nos que toda e qualquer educação é produto e produtora na dinâmica social e histórica. Pela produção ela mostra-nos a sua autonomia, pelo resultado produzido ela mostra a sua dependência. A falta de uma verdadeira educação humanista fez votar a própria cultura educativa à manipulação quantitativa especializada. $\mathrm{O}$ critério de verdade na ciência transformou-se apenas naquele fragmento de significação dado dentro de um compartimento disciplinar. O que mostra que aprender é um processo situado dentro de uma realidade partilhada simbolicamente. Neste sentido, existem tantos currículos quantas verdades possíveis.

Os cânones educativos são legitimados na própria assunção legal de que há uma predisposição para cada um destes compartimentos científicos. A naturalização das 
capacidades cognitivas pela lei indica-nos uma cultura para o não discernimento. E uma educação que apenas oferece conhecimento recusa a confiança e a possibilidade de desenvolver o pensamento crítico. Isto também serve ao ensino académico. Neste sentido, as formas de conhecimento distribuídas no ensino secundário circunscrevem-se às ofertas de distinção no mercado de trabalho.

E é aqui que a neutralidade da educação se torna uma falsa questão. À promoção de diferentes culturas subjaz a perpetuação de subculturas marcadas pelos privilégios dos poderes políticos, culturais, sociais e económicos. A diferenciação curricular nada mais é do que mérito alcançado perante pontos de partida divergentes. O lugar de chegada é o mesmo. O ponto de partida diferente. A diferença é a presença do ser na sua não essencialidade. Por isso não pode o currículo académico cristalizar a sua identidade recusando a possibilidade de existência do diferente, da outridade $^{8}$, neste caso dos currículos técnicos e profissionais. A teoria curricular é o campo onde se devem analisar as diversas dimensões do currículo: dimensão epistemológica, ontológica, valorativa e política.

O domínio ideológico, que assume todas as dimensões atrás referidas, é assumido como a verdade mas as diferentes disciplinas curriculares, bem como os currículos não são mais do que diferentes perspectivas sobre o mesmo objecto: o mundo. E isso é representar. Representar é o poder de determinar o que é a verdade e é também o poder de dar identidade. Só assim se compreende a permanência e a estabilidade do ensino académico. Uma vez absorvida a diferença, a identidade hegemónica valida-se e afirma-se a si mesma.

Os alunos do ensino profissional não podem continuar a ser vistos como uma mera oferta ao mercado de trabalho que responde às necessidades empresariais e estatais. Foi esta visão (e outras tantas) que levou ao embrutecimento intelectual e à deseducação bastante instruída. É aqui que educar se transfigura num empreendimento ético onde a educação do ethos se sobrepõe à educação mercantil. A educação é mais do que o alcance do crescimento económico, seja ele regional, nacional ou europeu. A educação é antes de mais uma escolha onde o homem vai se definindo. É na escola que a identidade se assume através do currículo experienciado. $\mathrm{O}$ facto de ser uma força dissimulada não significa que não seja interiorizada. Isto tanto serve a alunos como a professores.

A intenção e acção educativa não são passíveis de serem uma exclusão disjuntiva. E isso significa operar no mundo. Tanto serve à mudança como ao conformismo. Apenas cada um pode analisar as suas próprias intenções e motivações e é aí que reside o valor moral da acção educativa. Uma análise às necessidades causais e ideológicas do conhecimento e das práticas educativas de cada um e por cada um é o princípio básico e fundamental da dimensão valorativa do acto educativo.

Não há uma identidade no ensino secundário. Melhor, ela não é $a$ identidade. A sua constituição é dada na relação com e pela diferença. A não compreensão da alteridade faz com que ela traga consigo o estigma. É a exclusão à partida. De facto, é visível esta exclusão dos currículos profissionalizantes quando o currículo académico se arroga como a identidade do ensino secundário. Para tal recorre a essencialismos e a simbolismos que nas relações e representações sociais decide quem é incluído e quem é que fica de fora. Valorizar não significa validar, ainda menos é sinónimo de verdade. São meros sistemas de classificação em que existe o nós (os académicos, a cabeça) e o eles (os que trabalham, as mãos).

No ensino secundário os cursos académicos são vistos como a norma, como $a$ identidade. O desvio, a diferença e a alteridade são constituídos pelas outras modalidades de ensino secundário, nomeadamente o ensino técnico-profissional. O Outro é o outro que não se identifica comigo. Temos então o Nós e o Eles. Mas será absurdo a identidade ter-se 
a si mesma como referência. Quer dizer, a identidade é constituída a partir da diferença num processo relacional e social que depende de relações de poder. É o momento em que se inclui e exclui. É o lugar da valorização e da classificação.

A incorporação de esquemas mentais disponibiliza um quadro fechado, geralmente não questionável, de património identitário. Mas é por este quadro que é possível a revisão de determinações não revistas. Só assim se compreende que alguns professores defendam a introdução das vias profissionalizantes no ensino secundário. É o poder de reconstrução da identidade. Neste caso, da identidade do ensino secundário. Apenas eles, agentes educativos, podem levar a cabo as reformas, ainda que o conservadorismo dentro do sistema possa produzir discordâncias. E isso exige ponderação reflexiva.

A educação (re)produz o contexto cultural e a contextualização cultural (re)produz a educação. Se a educação está ao serviço do poder, nomeadamente do poder político e económico, então a cultura é uma produção industrial onde a divisão do trabalho das ciências reflecte a distribuição das disciplinas académicas nas escolas sem que ao currículo seja dado um sentido holístico. Quais os critérios em que assenta a abertura destes cursos? São as vocações dos alunos? São os empregos disponíveis? Ou será que se pretende a condução especializada para não desprender o sujeito de uma profissão particular?

A diferenciação uniformizadora do ensino secundário não passa de uma integração situada entre o cientismo e a publicidade. Será mais importante repensar modos de introdução do pensamento crítico no mundo do que instruir para a função especializada no mercado de trabalho. É o momento em que a educação capitalista se assume como adestramento. Quem melhor assegura os resultados neste tirocínio é a ideologia. Por ela são construídos significados por conveniência política, social e económica.

Fica assim compreendida a repentina necessidade de introduzir o novo vocacionalismo nos currículos de ensino secundário e só assim se percebe a forte resistência dos professores a esta via de aprendizagem. Mas também é pela ideologia que se compreende as necessidades de um Estado que propõe objectivos sem meios. Não basta qualificar dos cidadãos a qualquer custo. É preciso que ocorra uma mudança de representações sociais. Esta mudança de ponto de vista jamais poderá ocorrer por decreto. As novas, iguais às antigas, ideologias mais não fazem do que fortalecer a hegemonia dentro de uma escola onde se processam indivíduos e saberes. Isto é, as novas oportunidades escolares continuam a promover a tradição selectiva e incorporação cultural. É a continuação de distribuição de significados que asseguram o controlo social através do aparelho ideológico do Estado mais eficaz: a escola.

Em nome da igualdade de oportunidades a ideologia, de forma eficiente e conveniente, acorrenta a este princípio uma pseudo neutralidade em que o sucesso ou insucesso do aluno depende exclusivamente dele próprio. Sem responsabilidades a serem assumidas ficam de fora o Estado, as escolas e os professores que estruturalmente transfiguram a ideologia numa espécie de violência silenciada pela alienação. E é aqui que a escola, enquanto aparelho ideológico do Estado, pode ser repressiva: pela exclusão. O ensino técnico-profissional é marcado por esta exclusão porque ele está destinado àquela franja da sociedade menos nobre e esta nobreza não assenta na mera riqueza. É aquele tipo de nobreza hereditária e elitista (s.nob. significa sem nobreza) que assenta em pressupostos culturais e sociais.

O currículo é cada vez mais entendido do ponto de vista técnico porque foi construído sob políticas educativas que substituíram o ideal democrático pelo ideal económico. É assim, na tecnocracia, que o currículo se demarca de orientações éticas e morais. Tudo, em educação, parece ser uma questão de engenharia que talou e desolou o universo e o homem. Por isso mesmo as disciplinas especializadas são incapazes de lidar 
com problemas de educação. É que estes problemas são problemas da existência humana. Em nome da ciência sobre o mundo os especialistas esquecem o que abraça e envolve esse mesmo mundo. A especialização categoriza coisificando os indivíduos porque uma vez desobrigados a examinar o contexto há uma naturalização do processo de rotulação. Temos os bons e os maus alunos a quem se dá uma segunda oportunidade de escolarização secundária através do ensino técnico e profissional. É esta a representação social que paira sobre a comunidade educativa.

As mãos, em alguns países, parecem ser ainda escravas do fascismo e não um instrumento de aprendizagem e de desenvolvimento cognitivo. Até porque, a nível da filogenia, foi pela mão que se desenvolveu a inteligência. A escola tem se escondido no paradigma científico motivando os alunos para o abandono escolar. A pseudo cientificidade do ensino secundário faz dele um mundo desligado do próprio mundo. Neste sentido, ele é visto como secundário, portanto, dispensável. Na ausência de perspectivas vitais o ensino secundário tem se limitado a desprezar a vida e aqueles que nos currículos do ensino secundário participam tornam-se efeitos desse mesmo currículo. É no confronto das forças do currículo, isto é, nas vontades que o movem, que encontramos já o seu poder: a sua latência.

Se por um lado o currículo formal é o reconhecimento da realidade, por outro lado ele é a assunção da possibilidade de visibilidade do real, quer dizer, ele é uma forma de representação do real carregada de elementos ocultos que se apresenta como o sentido que não aparece como evidência. O sentido do currículo é já a própria identidade que não se limita a reproduzir representações acerca da realidade. Ele também reproduz as estruturas sociais e assegura a (de)formação de consciências. Pelo currículo, oculto ou não, fica determinado quem é que está autorizado a representar o conhecimento. Esta representação tem sido deixada nas mãos dos cursos académicos (ainda que estes tenham menos sucesso escolar do que os cursos técnico-profissionais) que definem o que é conhecimento legítimo e quem a ele deve ter acesso. As altas taxas de desistências e de reprovações no ensino académico, particularmente nas áreas das ciências são a prova disso.

O sentido dado pela representação da realidade e do conhecimento transforma-se no real e no conhecimento. É o encontro da verdade num reconhecimento manco que classifica a realidade exterior e a realidade social. É este o poder da representação: decide identidades e fixa regras. Essas classificações são naturalizadas num conexo e contíguo jogo de poder desde o seu início despótico. A sua legitimação ocorre pela força das crenças dos membros do grupo que em nome da unidade aceitam a divisão comum. É assim garantida a distribuição de percepções e de categorias perceptivas. O currículo opera de igual modo.

A nobreza do currículo, nesta perspectiva, assenta não no conhecimento mas no tipo de percepção que temos do conhecimento e daqueles que a ele têm acesso. A subtracção de significados e reflexões impede que a escola se reconheça como um lugar onde as relações de poder operam silenciosamente. As representações sociais, daqueles que têm responsabilidades políticas na educação, da própria sociedade, das escolas, dos professores e dos alunos, interferem na educação dos discentes. E se o próprio currículo é representação a ser utilizada, ele também é representação autorizada. Por quem e porquê é a tarefa de reflexão de cada um.

O poder simbólico do currículo tem de ser descoberto onde ele se deixa ver menos. Quanto à escola, ela normaliza o diferente em nome da homogeneização, onde a alteridade é sempre identidade categorizada como desvio à normalidade. E tudo o que não se encaixe neste valor de verdade é especial. Cremos, numa leitura horizontal, que é uma das modalidades de ensino dentro da escola secundária. Se a componente prática é o que o 
torna especial, então muito bem. Que o seja. Mas que isso não sirva para a estigmatização institucional. Mas não basta a reivindicação como resposta ao estigma. É preciso destruir os fundamentos e os mecanismos de dominação. O separatismo de pouco ou nada tem servido perante as culturas escolares hegemónicas. Na escola, dentro e fora dela a estigmatização pode ser abatida. Não basta auto-afirmação exclusiva. É preciso o mundo social intervir perante a arbitrariedade dissimulada.

As funções sociais do currículo assentam na criação de condições que permitem a acumulação de capital através da selecção dos alunos que reproduz a força do mercado de trabalho. Assim, os alunos das vias profissionalizantes fazem parte, na pirâmide social, do estrato menos favorecido porque a escola meritocrática legitima e garante a manutenção da desigualdade económica e cultural. Aos tipos de alunos produzidos irá corresponder tipos de percursos económicos.

O caso austríaco é o que melhor nos ilustra esta visão: os alunos são seleccionados, à saída do ensino primário, em função das suas notas escolares e assim é definido o seu destino escolar, académico e social. A elite austríaca resume-se a $28.9 \%$ dos alunos a frequentarem o currículo clássico, portanto académico, precisamente com o estudo do grego e do latim durante os oito anos que se seguem à escola primária e que são exigidos para frequência universitária. É que esta decisão vocacional cujo critério assenta nas notas quantitativas, vai determinar também o destino profissional e neste sentido, o destino social, cultural e económico da criança.

Assim, os alunos incapazes do ensino secundário carregam uma identidade subordinada cujo fracasso é delimitado antes de qualquer acção. É este o peso que carregam os alunos do ensino técnico-profissional em Portugal perante uma estereotipia que simplifica, com fórmulas facilitadoras, grupos culturais e sociais. O caricato destas perspectivas, no caso do ensino técnico-profissional, é que as suas componentes socioculturais e científicas são concebidas a partir dos currículos académicos. De qualquer modo, parece-nos que as orientações curriculares dadas pelo Ministério da Educação são insuficientes e que a existência de um currículo nacional flexível seria uma mais-valia ao mundo da educação.

Defendemos um currículo nacional suficientemente plástico para o reconhecimento das diferenças sociais e culturais da escola e que dialogue com as estruturas de poder. Que na escola se consiga encontrar relações publicamente discutidas permitindo assim a lucidez do diálogo heterogéneo. A ênfase dada ao ensino técnico-profissional no que concerne à preparação para o mundo do trabalho tende a se descuidar de uma educação para a compreensão crítica do mundo e se as práticas pedagógicas neste (ou noutro qualquer) tipo de ensino desconsidera este objectivo então não é digna de se chamar educação. $\mathrm{O}$ currículo não pode ser visto como teórico ou prático. Um currículo tem que se basear na experiência que reforça o desenvolvimento crítico. E isto assiste a qualquer tipo de currículo que defenda a igualdade de acesso e de oportunidades no ensino.

A difusão do ensino não trouxe a igualdade de oportunidades sociais. Também a escolaridade cada vez mais longa não implicou de modo algum maior esperança social. $\mathrm{O}$ fracasso educativo está para além dos alunos, dos professores e das escolas. Também não pode ser entendido como uma inevitabilidade do sistema económico, ou da perversa ideia de construção de um futuro socioeconómico melhor. Devemos questionar as intenções do corpo de conhecimentos que constituem o saber escolar.

Se a escola é um bem público então teremos que admitir que esse bem é publicamente marginalizado quando temos não apenas alunos e/ou escolas, mas currículos estratificados. A escola é o lugar onde se jogam com as dinâmicas económicas. Ela não é uma mera máquina de reprodução social. O seu cientismo tradicional impede que os 
professores possam pensar conteúdos diferentes e é neste sentido que o currículo deforma vozes cada vez mais ausentes. E se é verdade que os alunos são os que mais resistem aos currículos oficial e oculto, não menos verdade será que são os próprios alunos que fortificam as distâncias ideológicas. São eles que consideram os colegas do ensino técnicoprofissional menos apetrechados intelectualmente, mas também, por outro lado, são os próprios alunos destes cursos que muitas vezes afirmam ser mais fácil tirar um curso nesta via de ensino.

A educação tem implicações éticas, políticas e económicas e são as falsas consciências, ou a ausência delas, que permitem a distorção da realidade em nome da hegemonia que no âmbito escolar garante a produção de identidades em função das classes sociais através das suas muitas formas de poder: o conhecimento. Na mesma escola mundos diferentes são ensinados e incorporados através do currículo. Isto significa que a catalogação dos alunos é feita a priori pelo currículo.

Qualquer reflexão sobre as relações da escola com o poder tem que ser realizada antes e não depois das práticas educativas. Só assim se compreende por que é que a escola participa na criação de vencedores e perdedores. Por muito que o ensino técnicoprofissional se esforce por ligar o conhecimento à vida, a sua fraqueza assenta no facto de se dirigir à vida profissional que há-de vir e não à vida dos homens. Ao ensino académico nem lhe é possível compreender a que se refere esta visão. A compartimentação disciplinar é de tal modo especializada e abstracta que o desvio do sensível, portanto do mundo, é natural e até mesmo desejado. Quanto mais especializado e abstracto for o conhecimento mais funciona como construtor de subjectividades. É um trabalho solitário orientado para a literacia que se opõe ao trabalho cooperativo orientado para a oralidade do ensino profissional.

A determinação das modalidades de ensino secundário pelo poder fez do conhecimento refém desse mesmo poder que autoriza financiamentos, status e perspectivas de carreiras. É aqui que a escola se subjuga ao Estado. A resistência e a oposição que podemos encontrar face aos mecanismos de reprodução social não significam forçosamente emancipação. A radicalidade conduz, não raras vezes, à negação da dissensão.

Os professores foram (uns mais do que outros), de facto, disciplinados pela distribuição de recursos, perspectivas de trabalho e de carreira que definem o status do conhecimento por eles ensinado. A educação vocacional não tem por objectivo preparar apenas profissionalmente. Tem como preocupação fundamental orientar a maioria dos estudantes de status mais baixo para as suas ocupações futuras e oferecer-lhes ainda a possibilidade de um pensamento crítico que não vê nessa preparação um fatalismo social. Vocacional não é sinónimo de boçal. Claro está que o currículo académico não recusa o seu propósito vocacional, mas destina-se às profissões de status mais elevado. Ambas as vias de ensino, cursos gerais e profissionais, são vocacionais, mas apenas um itinerário se destina ao mundo comum do trabalho: o ensino profissional.

O conhecimento útil é visto como senso comum porque a tradição académica dá preferência à cabeça sobre as mãos. E não há aqui neutralidade possível. É clara divisão social do conhecimento e a divisão social do trabalho. Assim, o currículo é o lugar de lutas sociais que concorrem na distribuição desigual da riqueza e do poder ${ }^{9}$. A escola, os seus parceiros e agentes, apesar das suas tentativas de dissimulação de dominação de classe, aceitam esta divisão social como algo de evidente. É esta a força ideológica do currículo. É aqui que o currículo se torna um instrumento explícito de poder. 
Se as novas ideologias, tal como as antigas, servem para impedir a discussão dos fundamentos sociais também teremos que admitir que à nossa consciência ninguém tem acesso. Em educação a pergunta que nos inquieta é: alunos de diferentes origens sociais têm as mesmas oportunidades de vida? Não cremos. Ainda que a escola secundária tenha tentado diversificar, somiticamente, as vias de formação ela não foi capaz de produzir efeitos positivos devido à sobredeterminação académica que desvaloriza socialmente tudo o que seja diferente dela. A configuração do conhecimento curricular também forma identidades que ultrapassam a instituição escolar transpondo essas identidades para as estruturas económicas e políticas. É assim que se dá a produção social da identidade e da diferença. Criadas as categorias e os atributos a serem entregues a um indivíduo dá-se a coincidência entre a identidade social e a identidade real. Uma vez dado o atributo e criado o estereótipo temos o estigma.

É urgente uma reflexão sobre as nossas representações sociais e culturais, isto é, uma análise crítica acerca da organização social (inclusive na escola). Só assim é possível a regeneração social. É o pensar sobre o pensamento e sobre as crenças do mundo construídas pelo nosso próprio pensamento. Que se acrescente: e pelo pensamento dos outros. Se é verdade que a educação não cria a competência em ser, não menos verdade será que ela prepara esta capacidade. Isto não significa relegar para segunda importância o saber. Não é possível ser sem os conhecimentos. Saber ser é também saber fazer. É esta a mais-valia do ensino técnico-profissional. Nele estão pressupostos ambos os modos de ser.

Mas é neste saber fazer que se encontram as representações mais enviesadas acerca deste tipo de ensino: alunos insucedidos destinam-se ao funcionalismo pragmático. Um modo de transpor estas representações poderá ser linguisticamente, isto é, recomendamos a substituição da expressão "ensino profissional" por "ensino vocacional", mas que não se trate de uma mera operação estética conceptual. Que ensino vocacional se dirija às vocações dos alunos e que esta expressão evite erros de interpretação e de compreensão junto dos parceiros europeus. É possível a metamorfose do núcleo fundamental das nossas representações mentais através de uma outra diegese também ela assente em convicções sociais e pessoais.

É importante que a comunidade educativa seja capaz de lidar com o diferente onde a ideia de pessoa seja respeitada moral, física e juridicamente numa totalidade que é o indivíduo concreto. Cada totalidade particular é constituída pela sua singularidade e às diferenças de personalidade subjazem os traços, ou padrões de comportamento também eles determinados pelas situações que produzem atitudes. Mas é também pela atitude que são possíveis modificações já que isso implica reformulação da intenção comportamental. Assim, quanto maior for a importância do modelo (ensino académico) para os membros do grupo (professores) menor será a sua tolerância para com aqueles que estejam fora da norma (alunos do ensino técnico-profissional). A norma não se limita a unificar um sistema de referências. Ela reduz diferenças, conflitos e a possibilidade do diálogo. Nascem e enraízam-se os preconceitos em nome da coesão. O que se ganha em unidade perde-se em interacção.

O compromisso só é possível quando se dá a união dos divergentes. Por isso mesmo, quanto menos pessoas participam menos o consenso é legítimo. A falta de confronto dialógico sobre as vias de formação no ensino secundário é um exemplo disto. Poderiam as escolas organizar debates onde a discussão não extremasse posições mas desenvolvesse o pensamento analítico desconstrutor de saberes enraizados. O que não pode acontecer é esta contínua indiferença e conformismo que levam a decisões abusivas e enganosas em educação.O engano assenta, em geral, na frequência, mutabilidade e relação de traços de personalidade que formam teorias implícitas que mais não são do que crenças 
gerais acerca da realidade. São teorias ingénuas do mundo que categorizam sem rever os elementos novos. Mas é a categorização que nos guia na execução. No entanto, a categoria não é livre de ser falsificada, quer dizer, se é imagem e aparência ela pode ser desmascarada e despida. De uma maneira ou de outra, a representação tem o poder de modificar o próprio funcionamento cognitivo. Assim, as representações acerca do ensino técnico-profissional modificam o desenvolvimento e as estruturas cognitivas dos alunos que por esta via optaram.

O alcance das representações sociais é que elas se transformam em conhecimento social. Isto significa que a representação é tanto social como individual, o que não significa que seja real nem ideal. Não é mera reprodução. É construção, processo e relação. É a evocação do passado e do futuro que orienta condutas e práticas sociais (scripts) que se instalam no património cultural. A categorização, seja por representação social seja por scripts, constroem teorias que transfiguram os factos. É o extremismo do senso comum que pela significação oculta elimina a diversidade em nome da homogeneização social. $O$ mesmo acontece na escola. Quer dizer, é o exercício do controlo social dentro das instituições educativas que distribui formas de consciência onde cada homem deve se ajustar às categorias propostas. Por isso, generalizar é hipersimplificar e aqui corremos o risco de excluir por deformação intelectual e moral.

Assim, não são os factos que engendram ou destroem as nossas crenças. São as nossas crenças fazem nascer os factos. O objectivo é garantir o controlo e a predizibilidade do mundo social. Uma vez aceites, as teorias implícitas muito dificilmente são modificadas e a escolha por uma teoria tem por base a defesa da ordem, da disciplina e do status quo. Mas não é impossível a alteração às teorias implícitas enraizadas. Pela mudança do contexto histórico e ideológico, da consciencialização individual e por uma verdadeira revolução científica haverá o dia em que nenhum saber será mais fundamental que outro.

As crenças são sempre apostas e o ensino profissional deverá ser objecto de aposta não só pela escola e pelo Estado, como pela sociedade. Para já não existe uma verdadeira inclusão dos alunos do ensino profissional nas escolas secundárias públicas precisamente porque a normalidade garante a identidade hegemónica. Mas também deveremos acrescentar que o normal não tem nada de especial ${ }^{10}$. Há, de facto, uma integração escolar dos alunos do ensino técnico-profissional nível III nas escolas públicas. Mas essa integração é já um modo de exclusão.

A escola exclusiva torna-se privilégio monopolista. É esse o sentido de exclusividade. Por isso mesmo não poderemos falar de verdadeiro insucesso e abandono escolar no ensino secundário português enquanto não houver na escola pública uma real e efectiva oferta curricular de todas as modalidades de ensino e enquanto os diversos países não forem capazes de oferecer uma formação, inicial e contínua, de professores na área do ensino técnico-profissional. Só pela inclusão pode ser realizado o ideal da igualdade de oportunidades. Mas esta visão é, provavelmente, também ela uma teoria implícita.

\section{BIBLIOGRAFIA}

ALTHUSSER, L. (1974). Ideologia e Aparelhos Ideológicos do Estado. Lisboa: Ed. Presença

ALVES, M. J. (1999). Crises e Dilemas do Ensino Secundário - em busca de um novo paradigma. Porto: CRIAP - Ed. ASA

ALVES, M. J. (2000). O primeiro de todos os ofícios. Porto: CRIAP - Ed. ASA

Revista HISTEDBR On-line, Campinas, número especial, p. 191-205,ago.2010 - ISSN: 1676-2584 204 
CORREIA, J. A. (1996). Sociologia da Educação Tecnológica. Lisboa: Universidade Aberta

CORREIA, M. A. (1995). Escolas profissionais: entre o mercado de trabalho e o mercado escolar - estudo de caso. (policopiado). Faculdade de Psicologia e Ciências da Educação. UNIVERSIDADE DO PORTO. (dissertação de mestrado).

GOODSON, F. I. (1997). A Construção Social do Currículo. Lisboa: Educa

GOODSON, F. I. (1999). Currículo: Teoria e História. Petrópolis: Ed.Vozes

GOODSON, F. I. (2001). O Currículo em mudança-estudos na construção social do currículo. Porto: Porto Ed.

SILVA, T. T. (1999). O Currículo Como Fetiche - a poética e a política do texto curricular. Belo Horizonte: Ed. Autêntica

SILVA, T. T. (2000). Teorias do Currículo, uma introdução crítica. Porto: Porto Ed.

SILVA, T. T. (org.) (1998). Alienígenas na sala de aula - uma introdução aos estudos culturais. Petrópolis: Ed. Vozes. $2^{\mathrm{a}}$ ed.

SILVA, T. T. (org.) (2000). O Sujeito da Educação - Estudos Foucaultianos.Petrópolis: Ed. Vozes. $4^{\mathrm{a}}$ ed.

SILVA, T. T. (org.). (2000). Identidade e diferença - a perspectiva dos estudos culturais. Petrópolis: Ed. Vozes

STOER, S., STOLEROFF, A. e CORREIA, A., (1990). O Novo Vocacionalismo na Política Educativa em Portugal e a Reconstrução da Lógica da Acumulação, Revista Crítica de Ciências Sociais, n. ${ }^{\circ} 29$.

\section{OUTRAS FONTES}

- $\quad$ Lei n. $^{\circ} 46 / 86$

- Relatório do Conselho Europeu sobre Educação, Os objectivos concretos dos sistemas educativos - Cimeira de Lisboa

- http://jn.sapo.pt/2008/02/19/economia e trabalho/licenciados desemprego_duplicaram ci. $\underline{\mathrm{html}}$

\footnotetext{
${ }^{1}$ CORREIA, J. A., Sociologia da Educação Tecnológica, pp.51 a 68

${ }^{2}$ Em Portugal os cursos de qualquer uma destas modalidades de educação têm, em geral, uma duração de três anos

${ }^{3}$ GOODSON, I., A construção social do currículo, p. 100

${ }^{4}$ ALVES, M., Crises e Dilemas do Ensino Secundário - em busca de um novo paradigma, p. 28

${ }^{5}$ Lei n. ${ }^{\circ} 46 / 86$, Artigo n. ${ }^{\circ} 3$, i)

${ }^{6}$ Relatório do Conselho Europeu sobre Educação, Os objectivos concretos dos sistemas educativos - Cimeira de Lisboa, p. 31

${ }^{7}$ http://jn.sapo.pt/2008/02/19/economia_e trabalho/licenciados_desemprego_duplicaram_ci.html

${ }^{8}$ SILVA, T. T., Identidade e Diferença - A perspectiva dos Estudos Culturais, p.79

${ }^{9}$ GOODSON, I., O Currículo em Mudança - Estudos na Construção Social do Currículo, p. 196

${ }^{10}$ Ver filme de Alexandre Payne, Les Gens Normaux n'ont Rien d'Exceptionnel, 1993

Recebido dia 10/03/2010

Avaliado dia 20/04/2010
}

Revista HISTEDBR On-line, Campinas, número especial, p. 191-205,ago.2010 - ISSN: 1676-2584 205 